\title{
Morphological and Morphometric Aspects of Crassostrea rhizophorae (Guilding, 1828) Oocytes in Three Stages of the Gonadal Cycle
}

\author{
Aspectos Morfológicos y Morfométricos de Oocitos de Crassostrea \\ rhizophorae (Guilding, 1828) en Tres Fases del Ciclo Gonadal
}

"Ferreira, M. A. P.; " Paixão, L. F.; ${ }^{* *}$ Alcântara-Neto, C. P.; "Santos, S. S. D. \& *Rocha, R. M.

\begin{abstract}
FERREIRA, M. A. P.; PAIXÃO, L. F.; AlCÂnTARA-NETO, C. P.; SANTOS, S. S. D. \& ROCHA, R. M. Morphological and morphometric aspects of Crassotrea rhizophorae (Guilding, 1828) oocytes in three stages of the gonadal cycle. Int. J. Morphol., 24(3):437442, 2006.
\end{abstract}

SUMMARY: Crassostrea rhizophorae (Guilding, 1828) is one of the tropical species of oysters cultivated on the Brazilian shore. Despite its high commercial value, there is no information on the gonadal characteristics during the reproductive stages of this species. The objective of this work was to analyze the morphology and morphometry of Crassostrea rhizophorae oocytes and follicles in three stages of the gonadal cycle. Were analized histological sections of gonads considering that the oocytes presented visible nuclei and nucleoli, it was observed three gonadal cycle stages: early gametogenesis, growth and maturation. In the early gametogenesis stage, follicles and oocytes presented diameters of $180.29( \pm 41.91)$ and $18.66( \pm 6.85) \mu \mathrm{m}$, respectively, and presence of large amount of connective tissue and previtellogenic oocyte. In the growth stage, follicles and oocytes presented diameters of $218.02( \pm 43.19)$ and 25.92 $( \pm 9.94) \mu \mathrm{m}$, respectively, this stage was characterized by a small amount of interfollicular connective tissue with vitellogenic oocyte predominate. In the maturation stage, follicles and oocytes presented diameters of $298.16( \pm 99.24)$ and $35.27( \pm 6.2) \mu \mathrm{m}$, respectively, and presence of large number of mature oocytes. We concluded that during culture Crassostrea rhizophorae tolerates the influence of intrinsic and extrinsic factors and does not undergo significant changes in reproductive activity.

KEY WORDS: Crassostrea; Oocyte; Gonad; Morphology.

\section{INTRODUCTION}

Crassostrea rhizophorae (Guilding, 1828) popularly know as Mangue (mangrove) Oyster, Gaiteira Oyster or Gureri (Boffi, 1979) is one of the cultivated tropical oyster on the Brazilian shore with high commercial value (Vélez, 1977; Boffi, 1979; Gosling, 2003). Currently, Crassostrea rhizophorae culture is being implemented in Pará (AlcântaraNeto, 2004). However, there is no information on the gonadal characteristics during the reproductive stages of this species.

The gametogenic cycle of bivalve mollusk can be evaluated by measuring samples and through gonad color (Mattox, 1949; Mason, 1958; Saenz, 1965; Velez, 1976), gonad histological analysis (Velez, 1977; Stephen, 1980; Lopez \& Gomes, 1982; Braley, 1984; Fournier, 1992; Barber, 1996) or more recently by associated histological and quantitative methods (Choi \& Chang, 2003).
Nevertheless, the studies carried out make no correlation between follicular components or acinus and gametogenic cycle stages. Thus, the objective of this work was to analyze the morphology of Crassostrea rhizophorae gonad, taking oocytes and follicles in three stages of the gonadal cycle as parameters.

\section{MATERIAL AND METHOD}

a) Sample. Specimens of Crassostrea rhizophorae oysters were cultivated in Nova Olinda, Augusto Corrêa-Pará. Annual average water temperature and salinity were $27.4^{\circ} \mathrm{C}$ and 35.8 p.p.m., respectively. Some samples were collected between April and November, 2004 and taken live to the

\footnotetext{
* Departamento de Histologia e Embriologia, CCB- Universidade Federal do Pará, Belém- PA, Brasil.

** Instituto de Ensino Superior da Amazônia - IESAM- Pará, Brasil.
} 
histological rechnique laboratory of Universidade Federal do Pará. The oysters were opened and the gonads were removed and fixed in Bouin solution, for 24 hours.

b) Light microscopy. After fixation, the oysters were dehydrated with concentrated graded ethanol series immersed and included in paraffin. Serial $5 \mu \mathrm{m}$ thick sections were submitted to Hematoxylin and Eosin. The samples was examined and photographed with and optical microscope (Olympus X30).

c) Morphometric analysis. Aided by a model linear reticule $(\mu \mathrm{m})$ histological sections of gonads were analyzed. Only oocytes that presented nuclei and nucleoli were considered. ANOVA and Kruskal-Wallis tests were used and value differences with probability $\leq 0.05$ were considered significant.

\section{RESULTS}

Histological Analysis. In the Crassostrea rhizophorae specimens analyzed it was observed gonads in three gonadal cycle stages early gametogenesis, growth and maturation.

In the early gametogenesis stage (Figs. 1a, 1b) average follicles diameter was $180.29( \pm 41.91) \mu \mathrm{m}$ in size and were involved by a large amount of connective tissue. The follicle lumen contained previtellogenic oocyte with diameter average 18,66 $( \pm 6.85) \mu \mathrm{m}$ in size and some vitellogenic oocytes.

In the growth stage (Figs. 2a, 2b) was characterized by a small amount of interfollicular connective tissue. The follicles diameter presented an average size of 218.02 ( \pm 43.19$) \mu \mathrm{m}$. Few previtellogenic oocyte were found an the interior and vitellogenic oocyte predominated. The oocytes diameter presented an average size of $25.92( \pm 9.94) \mu \mathrm{m}$. Some mature oocytes characterized by free follicle lumen were also observed.
The maturation stage (Figs. 3a, 3b) was characterized by a small amount of connective tissue with thin follicular wall. Follicles presented an average size of 298.16 ( \pm 99.24$)$ $\mu \mathrm{m}$, some vitellogenic oocytes and a large number of mature oocytes with average size of $35.27( \pm 9.94) \mu \mathrm{m}$. The latter were characterized by a round shape, large volume, large nuclei and few visible nucleoli. No previtellogenic oocytes were observed in this stage.

Statistical analysis. It was observed a total of 6050 measures from oocyte nucleus diameter (2250), oocyte diameter (2250) and follicle diameter (225) measures and oocyte-per-follicle count (225). The results are given in Table I.

\section{DISCUSSION}

The gonadal analysis of bivalve molluscs in an essential tool to understand the reproductive biology of the species and in the future to promote mechanisms for the preservation of these animals and their later production in a low cost subsistence food environment (Soudant et al., 1999; Gosling; Al- Mohanna, 2003).

The classification of the gametogenic cycle of bivalve molluscs is very complex and not standardized groups and even within genus. They are generally divided in five stages: undifferentiated, partial development, total development, egg laying and regeneration (Gosling). Nevertheless, some authors proposed their own classification according to the species studied as for example, Crassostrea rhizophorae (Velez, 1977), Ostrea iridescens (Fournier), C. gigas kumamoto (Robinson, 1992), C. gigas (Steele \& Mulcahy, 1999) and Pinctada fucata martensi (Choi \& Chang). We have described three gametogenic cycle stages in Crassostrea rhizophorae female studies: early gametogenesis, growth and maturation. This classification was based on the histological similarty between the bivalves mentioned above. It is possible that there also is

Table I. Oocyte nucleus, oocyte and follicle diameters and oocyte-per-follicle count in the three gonadal developmental stages of the Crassostrea rhizophorae.

\begin{tabular}{|c|c|c|c|c|}
\hline $\begin{array}{c}\text { Gonad } \\
\text { Development }\end{array}$ & $\begin{array}{c}\text { Oocyte nucleus } \\
\text { diameter }\end{array}$ & Oocyte diameter & Follicle diameter & $\begin{array}{c}\mathrm{N}^{0} \text { of oocy tes/ } \\
\text { follicle }\end{array}$ \\
\hline Early gametogenesis & $\begin{array}{c}10.13 \\
( \pm 3.81)^{\mathrm{a}}\end{array}$ & $\begin{array}{c}18.66 \\
( \pm 6.85)^{\mathrm{a}}\end{array}$ & $\begin{array}{c}180.29 \\
( \pm 41.91)^{\mathrm{a}}\end{array}$ & $\begin{array}{c}24.44 \\
( \pm 6.61)^{\mathrm{a}}\end{array}$ \\
\hline Growth & $\begin{array}{c}14.55 \\
( \pm 5.68)^{\mathrm{b}}\end{array}$ & $\begin{array}{c}25.92 \\
( \pm 9.94)^{\mathrm{b}}\end{array}$ & $\begin{array}{c}218.02 \\
( \pm 43.19)^{b}\end{array}$ & $\begin{array}{c}24.36 \\
( \pm 5.03)^{\mathrm{b}}\end{array}$ \\
\hline Maturation & $\begin{array}{c}22.81 \\
( \pm 4.38)^{c}\end{array}$ & $\begin{array}{c}35.27 \\
( \pm 6.2)^{c}\end{array}$ & $\begin{array}{c}298.16 \\
( \pm 99.24)^{\mathrm{a}}\end{array}$ & $\begin{array}{c}34.4 \\
( \pm 12.98)^{c}\end{array}$ \\
\hline
\end{tabular}



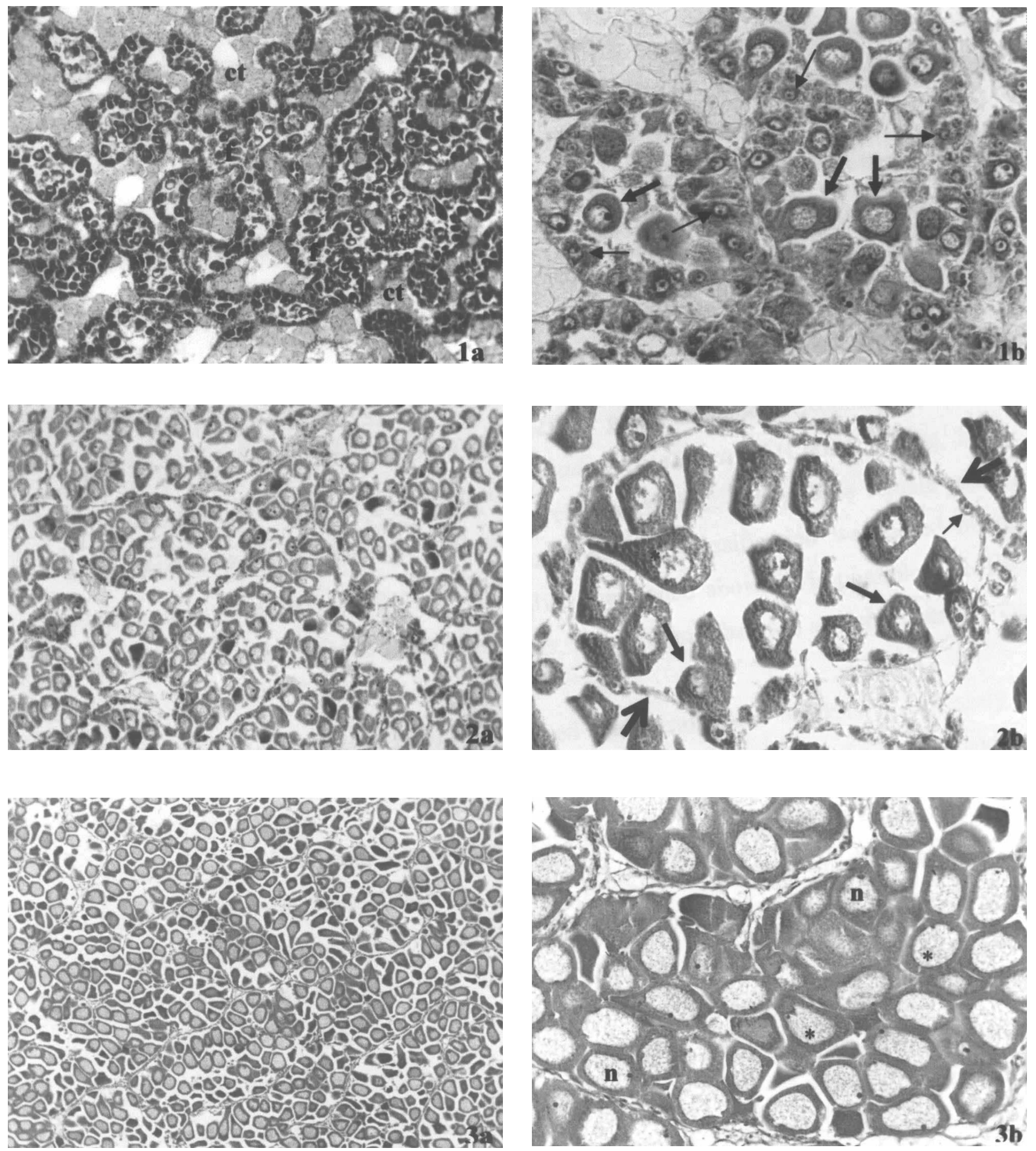

Figs. Female Gonad Crassostrea rhizophorae: 1a. Early gametogenesis stage - follicles (f) involved by connective tissue (ct) -100X. 1b. Note the presence of previtellogenic oocytes (thin arrow), vitellogenic oocytes (thick arrow) - 400X. 2a. Growth stage. 100X. 2b. Detail of the thin follicular wall (large arrow), previtellogenic oocytes (thin arrow), vitellogenic oocytes (thick arrow) and some mature oocytes (*) 400X. 3a. Maturation stage. 100X. 3b. Detail of mature oocytes (*) in lumen, very visible nucleus (n). 400X. H\&E staining. 
an undifferentiated stage, however, we have not observed any specimens in this phase.

Barber \& Blake (1991) described that histological analysis is necessary to demonstrated reproductive events during the gonadal development of a bivalve and that the quantitative method contributes with accurate and less subjective information on organ description. Our findings show a progressive increase in the average oocyte size/follicle diameter: $18.66 \mu \mathrm{m} / 180.29 \mu \mathrm{m}$ in early gametogenesis, 25.92 $\mu \mathrm{m} / 218.02 \mu \mathrm{m}$ in growth and $35.27 \mu \mathrm{m} / 298.16 \mu \mathrm{m}$ in maturation stages. The sequence of the stages and oocyte diameters found differ from those described by LangoReynoso et al., (2000) in their study of C. gigas. According to them, oocytes reached maximum diameter of $46 \mu \mathrm{m}$ in the degeneration stage, which takes place after maturation. This difference between species can be associated to environmental and genetic differences between populations, which may result in variations in the gametogenic process of the species (Yakovlev, 1977; Lango-Reynoso et al.).

Analyzing the cells in the follicle we found oocytes: previtellogenic, vitellogenic and mature. So far, it has been possible to describe the morphology of these cells only by ultrastructural method. Al- Mohanna et al., reported oogenesis of the Amiantis umbonella and described primary and secondary protogonia and previtellogenic and vitellogenic oocytes. The differences between these phases are based in the accumulation of the lipidic and granule cytoplasm content. Although they do not belong to the same genus, Crassostrea rhizophorae presents oocyte morphology similar to that of $A$. umbonella. In $C$. virginica macromolecules of the yolk are heterosynthetically incorporated into the oocytes from the haemocel (Eckelbarger \& Davis, 1996). The analysis of the vitellogenesis by immunocytochemical study showed that it results from proteins present in the haemocel and from others located in the ovary itself, in C. gigas (Suzuki, et al., 1992) and in other species (Tseng, et al., 2001; Okumura et al., 2004).

We also analyzed the diameter of oocyte nucleus and the number of oocytes per follicle and found larger oocytes in the maturation stage; however, the average number of oocytes/ follicle was practically the same in the early and growth stages, and larger in the maturation stage. This fact can be explained by the presence of some previtellogenic oocytes that had a late development due to intrinsic and/or extrinsic factors.

The gametogenic cycle of Crassostrea rhizophorae must be similar to those of other bivalves even thought we have not described an annual cycle. The aim of this work was to describe the gonads of this mollusk during the culture, mainly the morphology and the organization of the oocytes, particularly in the early gametogenesis, growth and maturation stages. These data reflect the moment the gonad is in development in the reproductive cycle, probably under the influence of intrinsic factors such as steroid hormones (Matsumoto et al., 1997) and of extrinsic factors such as temperature, salinity and nutrients (Stephen; Fournier; Robinson; Choi \& Chang and Moraga et al.).

Velez (1977) reported that Crassostrea rhizophorae reproduces asynchronously resulting in a continual production of gametes along the year with minimal activity from January to June and maximal activity from July to November. We analyzed oyster in the April-November period and found synchronism between males and females (data not published). However, females presented a gradual development with a larger number of oocytes in November. Thus, we can conclude that during culture, the Crassostrea rhizophorae tolerates the influence of intrinsic and extrinsic factors and does not undergo significant changes in reproductive activity.

FERreira, M. A. P.; PAIXÃo, L. F.; ALCÂNTARA-NETO, C. P.; SANTOS, S. S. D. \& ROCHA, R. M. Aspectos morfológicos y morfométricos de Oocitos de Crassostrea rhizophorae (Guilding, 1828) en tres fases del ciclo gonadal. Int. J. Morphol., 24(3):437-442, 2006.

RESUMEN: Crassostrea rhizophorae (Guilding, 1828) es una de las especies de ostras tropicales cultivadas en la costa brasilera, que presenta alto valor comercial, no existiendo información sobre las características gonadales, durante las fases reproductivas de esta especie. El objetivo de este trabajo fue analizar la morfología de los ovocitos y de los folículos gonadales de Crassostrea rhizophorae, en tres fases del ciclo gonadal. Analizando los cortes histológicos de las gónadas y considerando los ovocitos que presentaban núcleo y nucléolo evidentes, fueron determinadas tres fases del ciclo gonadal: gametogénesis inicial, crecimiento y maduración. En la fase de gametogénesis inicial, el diámetro de los folículos y de los ovocitos era de 180,29 ( $\pm 41,91)$ e 18,66 ( $\pm 6,85) \mu \mathrm{m}$, respectivamente; también identificamos gran cantidad de tejido conjuntivo interfolicular y un número mayor de ovocitos previtelogénicos. En la fase de crecimiento, el diámetro de los folículos y de los ovocitos era de 218,02 $( \pm 43,19)$ y 25,92 $( \pm 9,94) \mu \mathrm{m}$, respectivamente. Este fase fue caracterizada por una pequeña cantidad de tejido conjuntivo interfolicular y predominio de ovocitos vitelogénicos. En la fase de maduración, el diámetro de los folículos y de los ovocitos era de 298,16 ( $\pm 99,24)$ y 35,27 $( \pm 6,2) \mu \mathrm{m}$, respectivamente, existiendo gran número de ovocitos maduros. De esta manera, concluimos que durante la implantación del cultivo, Crassostrea rhizophorae tolera la influencia de los factores intrínsecos y extrínsecos y no presenta alteraciones significativas en su actividad reproductiva.

PALABRAS CLAVE: Crassostrea; Ovocito; Gónada; Morfología. 


\section{REFERENCES}

Alcântara-Neto. P. C. Moluscos Bivalves: um programa de ciência e tecnologia para a implementação da cadeia produtiva de moluscos bivalves no Estado do Pará. In: Simp. Brás. Aqüicult. Biol. Aquát. Vitória, Espírito Santo, $422,2004$.

Al-Mohanna S. Y.; Al- Rukhais, L. B. \& Meakins, R.H. Oogenesis in Amiantis umbonella (Mollusca:Bivalvia) in Kuwait Bay, Kuwait. J. Mar. Biol. Assoc. U.K., 83: 1065-72, 2003.

Barber, B. J. Gametogenesis of eastern oysters, Crassostrea virginica (Gmelin, 1791) and Pacific oysters, Crassostrea gigas (Thunberg, 1793) in disease-endemic lower Chesapeake Bay. J. Shellfish Res., 15(2):285-90, 1996.

Barber, B. J. \& Blake, N. J. Reproductive physiology. In: S. Shumway (Editor), Scallops; Biology, Ecology and Aquaculture. Elsevier, Amsterdam, 41: 377-428, 1991.

Berthelin, C.; Kellner, K. \& Mathieu, M. 2000. Storage metabolism on the pacific oyster Crassostrea gigas in relation summer mortalitier and reproductive cycle (west coast of France). Comp. Biochem. Physiol., 125:359-69.

Boffi, A.V. Moluscos brasileiros de interesse médico e econômico. Hucitec, São Paulo, 1979. 54p.

Braley, R. D. Mariculture potential of introduced oysters Saccostrea eucullata tuberculata and Crassostrea echinata and a histological study of reproduction of $C$. echinata. Aust. J. Mar. Freshwater Res., 35:129-41, 1984.

Choi, Y. H. \& Chang, Y. J. Gametogenic cycle of the transplanted culture pearl oyster, Pinctada fucata martensi (Bivalvia, Pteridae) in Korea. Aquaculture, 220: 781-90, 2003.

Eckelbarger, K. J. \& Davis, C.V. Ultrastructure of the gonad and gametogenesis in the eastern oyster Crassostrea virginica. I. Ovary and oogenesis. Mar. Biol., 127:7987, 1996.

Fournier, L. M. The reproductive biology of the tropical rocky oyster Ostrea iridensis (Bivalvia, Ostreidae) on the Pacific coast of the Costa Rica. Aquaculture, 101: 371-8, 1992.

Gosling, E. Bivalve molluscs: Biology ecology and culture fishing. New Books, 2003. 443pp.
Lango-Reynoso, F.; Villalba, J. C.; Cochard, J. C. \& Pennec, M.L. Oocyte size, a means to evaluate the gametogenic development of the Pacific oyster Crassostrea gigas. Aquaculture, 190:183-99, 2000.

López, M. D. \& Gómez, E. D. Reproductive cycles of the oysters Crassostrea echinata and C. lugubrious in Calatagan, Batangas, Philippines, Kalikasan. Philipp. J. Biol. 11(1):57-73, 1982.

Mason, J. The breeding of the scallop, Pecten maximus (L) in Many waters. J. Mar. Biol. Assoc. U.K., 37: 653 -71, 1958.

Mattox, T. W. Studies on the biology of the edible oyster, Ostrea rhizophorae Guilding in Puerto Rico. Ecol. Monog., 19:339-56, 1949.

Matsumoto, T.; Osada, M.; Osawa, Y. \& Mori, K. Gonadal estrogen profile and immunohistochemical localization of the steroidogenic enzymes in the oyster and scallop during sexual maturation. Comp. Biochem. and Physiol., 118:811-7, 1997.

Moraga, D.; Meistertzheim, A-L.; Tanguy-Rover, S.; Boutet, I.; Tanguy, A. \& Donval, A. Stress response in $\mathrm{Cu}^{2+}$ and $\mathrm{Cd}^{2+}$ exposed oysters (Crassostrea gigas): a immunohistochemical approach. Comp. Biochem. Physiol., 141:151-6, 2005.

Okumura, T.; Yoshida, K. \& Nikaido, H. Ovarian development and hemolymph vitellogenin levels in laboratory-maintained protrandic shrimp, Pandalus hypsinotus: measurements by a newly developed timeresolved fluoroimmunoassay (TR-FIA). Zool. Sci. 21: 1037-47, 2004.

Robinson. A. Gonadal cycle of the Crassostrea gigas kumamoto (THUNBERG) in Yaquina Bay oregon and optimum conditions for broodstock oyster and larval culture. Aquaculture, 106:89-97, 1992.

Saenz, B. El ostion antillano (Crassostrea rhizophorae) y su cultivo experimental en Cuba. Inst. Nac. de la Pesca, 7: 1-32, 1965.

Soudant, P.; Van, K.; Ryckeghem, K.V.; Marty, Y.; Moal, J.; Samain, J.F. \& Sorgeloos, P. Comparasion of the lipid class and fatty acid composition between a reproductive cycle in nature and standard hatchery conditioning of the Pacific oyster Crassostrea gigas. Comp. Biochem. Physiol., 123:209-22, 1999. 
Steele, S. \& Mulcahy, M. F. Gametogenesis of the oyster Crassostrea gigas in southern Ireland. J. Mar. Biol. Ass. U.K., 79:673-86, 1999.

Stephen, D. The reproductive biology of the indian oyster Crassostrea madrasensis. (Preston). Aquaculture, 21: 139-46, 1980.

Suzuki, T; Hara, A.; Yamaguchi, K. \& Mori, K. Purification and immunolocalization of a vittelin like protein from the Pacific oyster Crassostrea gigas. Mar. Biol., 113: 23945, 1992.

Tseng, D-Y.; Chen, Y-N.; Kou, G-H.; Lo C-F. \& Kuo, C-M. hepatopâncreas is rhe extraovarian site of vitellogenin synthesis in black tiger shrimp, Penaeus monodon. Comp. Biochem. Physiol., 129:909-17, 2001.

Vélez, A. Crescimento, edad y madurez sexual del ostión Crassostrea rhizophorae de Bahía de Mochima. Bol. Inst. Ocean., 15:65-72, 1976.

Vélez, A. Ciclo anual de reproducción del ostión Crassostrea rhizophorae (Guilding) de Bahía de Mochima. Bol. Inst. Ocean., 16:87-98, 1977.

Yakovlev, Y. M. Reproductive cycle of the Pacific oyster in the sea of Japan. Biology, Morya, 3:85-7, 1977.
Correspondence to:

Dra. Maria Auxiliadora Pantoja Ferreira

Centrode Ciências Biologicas

Departamento de Histologia e Embriologia

CCB- Universidade Federal do Para

Rua Augusto Corrêa - № 01 - Bairro: Guamá

CEP 66075-900

Belem- Pará

BRASIL

Email:auxi@ufpa.6r

Recibido : 09-02-2006

Aceptado: 22-06-2006 